\title{
Ruderal Plants in Urban and Sub-Urban Walls and Roofs Emrah YALÇINALP1 ${ }^{1}$, Alperen MERAL ${ }^{2 *}$
}

\author{
${ }^{1}$ Karadeniz Technical University, Faculty of Forestry, Department of Landscape Architecture \\ ${ }^{2}$ Bingol University, Faculty of Agriculture, Department of Landscape Architecture \\ *Correspondance: alperenmeral@bingol.edu.tr
}

\section{ABSTRACT}

Objective: Main purpose of this study is to identify the ruderal plant species which spontaneously grows on the wall and roof surfaces in urban and sub-urban areas due to their limited ecological needs and to contribute to the creating of the sustainable green areas in urban environments by understanding the parameters that ruderals depend on while they require little maintenance and irrigation support if not no.

Material and Methods: The main material of this study is the ruderal plants which were collected from totally 60 walls and 36 roof surfaces within six districts of Trabzon city Akçaabat, Arsin, Çaykara, Of, Ortahisar and Yomra in Turkey. From these 96 habitats, 1540 plants samples form the walls and 448 plant samples from the roofs were collected. All the plant samples collected from the research area were identified in the herbarium of the faculty of forestry in Karadeniz Technical University. Apart from this, parametres affecting coverage rate of common species on three different habitats were analysed.

Results: It was found that 448 samples from the roof surfaces distributed into 61 species while 1540 samples from the walls distributed into 196 species. Plus, according to the analyses, 28 species were found on all three different habitats. As a result of the observations, measurements and analyses, it is clear from the study that coverage rate of the plant species depends on anthropogenic interaction, daylight period and depth of the media but there is no relation with the number of the species on the surfaces.

Conclusion: Ruderal plants are definitely important to study on, if the world wants the term sustainability to find its real meaning as they require nearly nothing to grow in hard conditions. In urban life, maintenance is getting more and more expensive for green areas in urban life and this makes it difficult for them to survive especially when cities have limited budget on this, which has often occurred all over the world recently. There is no doubt that ruderal plants offer a great opportunity for modern era urban areas with their limited needs to grow in hard conditions. Furthermore, when thinking about the fact a serious amount of the ruderal plants detected on all three basic habitats has a great landscape plant characteristics, the approaches to their usage in urban areas are really critical.

Keywords: Urbanization, biological diversity, ruderal vegetation, roof, walls 


\section{INTRODUCTION}

Considering habitats within the context of ecological criteria, the habitats of herbaceous plants can be grouped as "Natural, Degraded, Ruderal and Artificial" (Hamel and Danserau, 1949; Yarc1 and Altay, 2016). Ruderal habitats are inhabited by mostly nitrophilous plants that develop on specific areas such as weathered areas, ruins and wall sides (Doğan et al., 2004; Altay and Karahan, 2017). Ruderal habitats may vary depending on the substrates of existing roads, transported soils and compacted rocks with different sizes (Frenkel, 1977). Ruderal plants growing in these habitats were also referred to as pavement plants, underfoot plants and stepable plants in various studies from Europe (Sukopp and Witting, 1998; Karahan et al., 2012).

Ruderal plants usually have a short life-span, propensity for rapid growth and reach their maximum reproductive capacity during the vegetation period (Pianka, 1970; Karaköse et al., 2018). Moreover, their single reproductive cycle, the high sensitivity of their seeds, the dispersion of their seeds to favorable and distant regions and their phenological flexibility help their adaptation to a wide range of environmental conditions (Sakai et al. 2011). They are usually distributed in non-competitive, disturbed areas; in other words, they can distribute in habitats that are non-stationary during the early successional stages of vegetation. They especially prefer regions with high rainfall and humidity (Karaköse et al., 2018).

The studies about ruderal vegetation types are rather new. As are natural communities, which are characterized by natural conditions, sub-urban communities are characterized by the conditions of inhabited areas (Hadac, 1978). Hence, ruderal vegetation is of great importance considering the industrialization of villages and the consequent destruction of the natural and semi-natural vegetation in these areas. In future, ruderal communities will be further needed as an indicator of the environmental conditions for the utilization of synanthropic vegetation (Şafak, 2015; Çetin and Mansuroğlu, 2018).

Determining the function of ruderal communities is not an easy task. Their effects are not thoroughly known and their quantitative measurement is a very challenging process. Ruderal vegetation has both positive and negative aspects (Hadac, 1978). Ruderal plants can easily colonize open soils and resist to erosion, are mostly nitrophilous and thus, can retain a significant amount of water and nitrate in soils. This is a considerably beneficial process due to its contribution to the inhibition of eutrophication in water basins. Furthermore, ruderal plants are cosmopolitan plants that are resistant to competition, their seeds can be dispersed even by car tires, they easily adapt to new environments, form ecotones, rapidly form large amounts of seeds, also referred to as pioneer plants, their seeds require a limited amount of nutrients for 
germination, they have rapidly growing roots and have the ability to form mycorrhizae (Anonymous, 2018a, 2018; Erik, 2012; Kılınç and Kutbay, 2008; Rentch et al., 2005; Heindl and Ulmann, 1991; Frenkel, 1977).

The studies about plant sociology became widespread in Turkey in the 1960s and thus far, numerous plant communities from different vegetations types were identified (Ketenoğlu et al., 2014). However, in Turkey, there are hardly any studies about ruderal vegetation, which is a broadly distributed vegetation type in urban ecosystems and regarded as a special type of vegetation (Yarcı and Altay, 2016; Altay, 2009; Güney et al., 2006; Çelik et al., 1998;).

There is little knowledge about these plants that characterize urban areas in which the majority of the world population reside. Therefore, there is a tremendous need for studies about ruderal plants to better understand cities. In light of this need, we came to conclude that investigating the special habitats that are specific to cities may yield interesting results and accordingly, the study was commenced. Walls and roofs, two urban habitats that do not exist in nature under normal circumstances and by their mere existence, prove the disturbance caused by humans comprise the growing environments that will be discussed in detail in the study. Within this scope, a study was carried out to identify the ruderal plant communities that are potentially distributed in the roof and wall vegetations. To compare and reveal the similarities and differences between urban ruderal vegetations, 30 sample areas that were selected among suburban areas were also included in the study. Considering the last 20 years, this was deemed necessary mostly due to the potential transformation of today's urban areas in many regions of the world into urban areas in near future. The study can thereby contribute to the detailed phytoecological and phytosociological studies about ruderal habitats in near future.

\section{MATERIAL and METHOD}

\section{Study Area}

The study areas consist of Akçaabat, Ortahisar, Yomra, Arsin, Of and Çaykara, which are towns of Trabzon City, Turkey, according to administrative boarders (Figure 1). The highest rate of urbanization is observed in Ortahisar in addition to its geographic location in the middle of the shoreline, which adds to its importance. The coastal region to the west of the town was examined by choosing Akçaabat as the representative of the region, while Yomra, Arsin and of were regarded as the representatives of the eastern region and Çaykara was regarded as the representative of the high inlands where the shore effect is relatively reduced. Location selection was carried out in this manner to ensure the examination of the entirety of the characteristics of different locations that are likely to be observed across the city. Trabzon is located between the slopes facing the north-west of the Kalkanlı mountainous mass in the 
middle of the arc formed by the Eastern Black Sea Mountains, at 38 $30^{\prime}-40^{\circ} 30^{\prime}$ E and $40^{\circ} 30^{\prime}-$ $41^{\circ} 30^{\prime} \mathrm{N}$ (Anonymous, 2018b). Trabzon covers an area of approximately $4.685 \mathrm{~km}^{2}$ and has a population of about 758.237, making it the second largest principal city in the region. The city is within the A8 of the grid system created by Davis 1965 and Davis 1988 and the annual mean rainfall is about $760 \mathrm{~mm}$, while the mean temperature is about $14.6 \mathrm{C}^{\mathrm{o}}$. The monthly mean temperature ranges from $7.3 \mathrm{C}^{\circ}$ in January and from 13 to $23.1 \mathrm{C}^{\circ}$ in August (Yalçınalp and Meral, 2017).
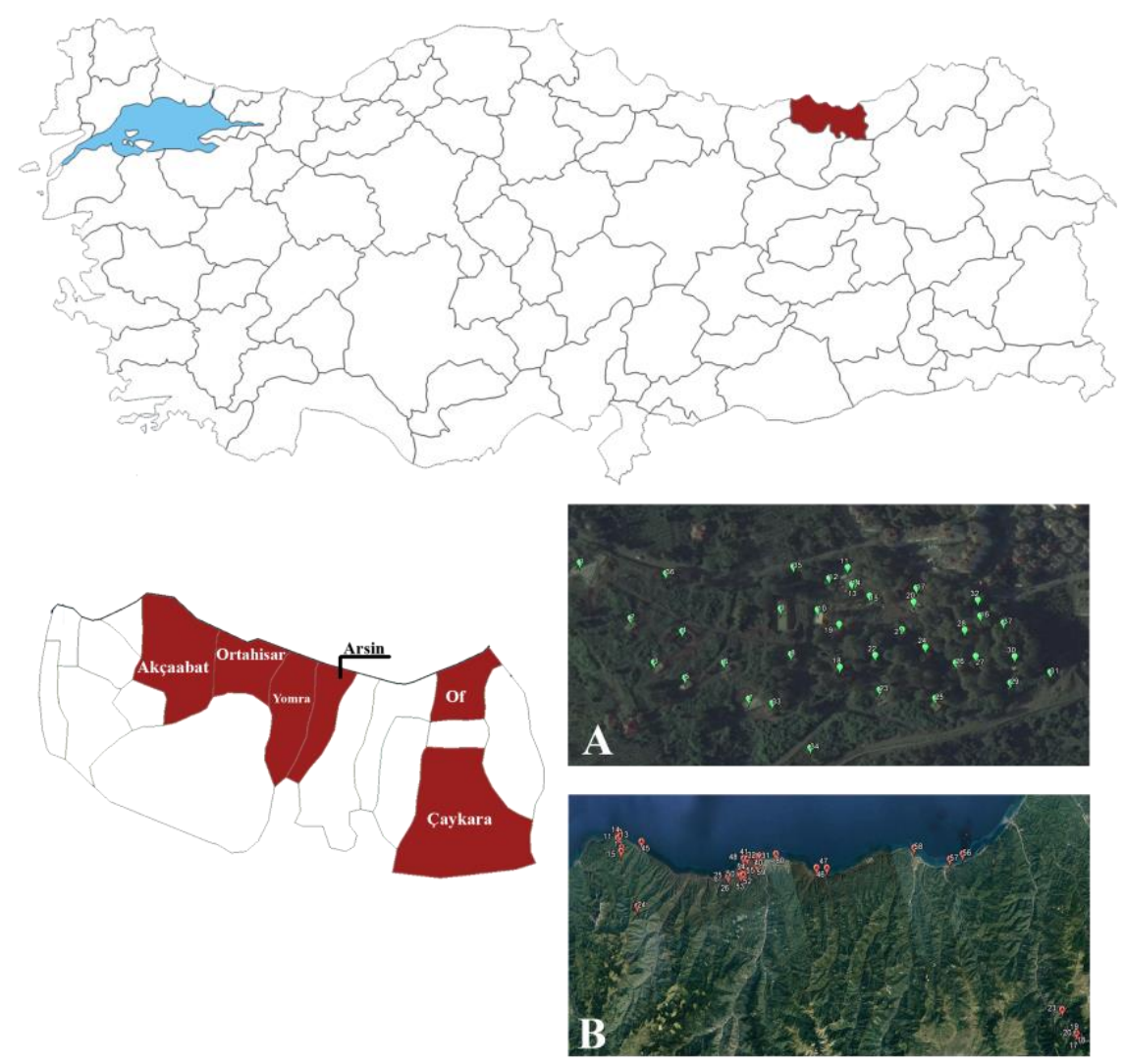

Figure 1. Study areas (A: Sample areas for the roof plants, B: Sample areas for the wall surfaces)

\section{Method}

\section{Sample Collection}

The study materials comprise the samples that were collected from 96 different areas after the wall and roof vegetation studies carried out in Trabzon during the period between 2013 and 2015. Among the 1540 samples (196 species) collected from the walls and 448 samples (61 species) collected from the roofs, 28 species that were commonly identified in both walls and roofs were classified according to the Grime's plant strategies (S, R, C) and included in the study. The plants were pressed and dried by following the standard herbarium methods and turned into herbarium materials. The plant species collected from the sample areas were 
identified using the Turkey Flora Index of the Herbarium of Karadeniz Technical University (Önen, 2015; Yüzbaşığlu, 2014; Eminağaoğlu et al. 2012; Coşkunçelebi et al., 2007; Terzioğlu et al., 2003; Güner et al., 2000; Terzioğlu and Anşin, 1999). The current status of the identified plants in the flora of Turkey was verified using the Turkey Plant List prepared by Güner et al., 2012. Raunkiær (1937) classified plants according to the place where the growth point is located during the less favorable seasons, provided the plant maintains the capability to survive these difficult conditions. The life-forms of the ruderal plants were determined in accordance with the system proposed by Raunkinaer, 1937.

\section{Data Analysis}

The analyses are based on the observations made of the plants that grew in the habitats in the study areas during the vegetation period between 2013 and 2015. The statistical analyses were performed using the SPSS Statistics 17.0 package program. In this study, Duncan and Regression analyses were performed to understand if there are meaningful differences between three different habitats and if there are hierarchical relations between the plant coverage rates on the wall and roof surfaces and the parameters affecting them.

\section{RESULTS}

Ruderal vegetation is a special type of synanthropic vegetation, which is the plant cover adapted to the conditions of residential areas that change due to anthropogenic factors (Figure 2) (Şafak, 2015).

For the further utilization of synanthropic vegetation in future, ruderal communities will be more needed.

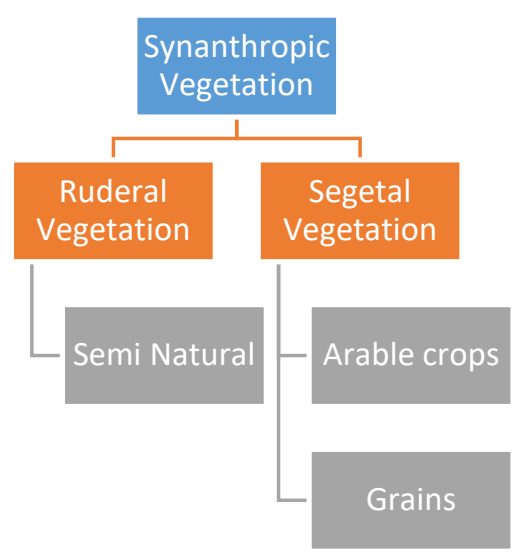

Figure 2. Ruderal vegetation and other similar vegetation types (Erik, 2012)

The vegetation comprising the ruderal plants in the study area was determined to be cosmopolitan and resistant to competition; plants with distinctly different ecological needs cohabited the area: their seeds were transported in various ways; plants easily adapted to the 
environment and created ecotones, rapidly formed large number of seeds, had the ability to form mycorrhizae; most importantly, their seeds had a considerably low nutrient requirement for germination (Table 1).

A total of 28 species from 18 different families were observed in the study area. Among the 28 species, $14(50 \%)$ showed natural dispersion, while the remaining $14(50 \%)$ do not show natural dispersion in Trabzon. The life-forms of the 28 species include Hemicryptophytes (15 species; 53.57\%), Phanerophytes (6 species; 21.43\%), Cryptophytes (3 species; 10.72\%), Chamaephytes (2 species; 7.14\%), Geophytes (1 species; 3.57\%) and Therophytes (1 species; $3.57 \%$ ) (Table 1).

Table 1. Common ruderal plant species in the study areas

\begin{tabular}{|c|c|c|}
\hline & Family & Species \\
\hline 1 & Aceraceae & Acer negundo \\
\hline 2 & Apiacea & Daucus carota \\
\hline 3 & \multirow[t]{7}{*}{ Asteraceae } & Bidens tripartita \\
\hline 4 & & Canyza canadensis \\
\hline 5 & & Cichorium intybus \\
\hline 6 & & Cirsium trachylepis \\
\hline 7 & & Sonchus asper \\
\hline 8 & & Tanacetum partherium \\
\hline 9 & & Taraxacum buttleri \\
\hline 10 & Caprifoliaceae & Sambucus ebulus \\
\hline 11 & Caryophllaceae & Stellaria media \\
\hline 12 & Cornacea & Cornus sanguiena \\
\hline 13 & Euphorbiaceae & Euphorbia peplus \\
\hline 14 & Fabaceae & Robinia pseudoacacia \\
\hline 15 & Geraniaceae & Geranium purpureum \\
\hline 16 & Lamiacea & Calamintha nepeta \\
\hline 17 & Moraceae & Ficus carica \\
\hline 18 & Oleaceae & Fraxinus angustifolia \\
\hline 19 & Oxalidaceae & Oxalis corniculata \\
\hline 20 & Primulaceae & Anagallis arvensis \\
\hline 21 & Ranunculaceae & Clematis vitalba \\
\hline 22 & \multirow[t]{4}{*}{ Rosaceae } & Agrimonia eupatoria \\
\hline 23 & & Cotoneaster figida \\
\hline 24 & & Geum urbanum \\
\hline 25 & & Rubus conhescens \\
\hline 26 & Simaroubaceae & Ailanthus altissima \\
\hline 27 & \multirow[t]{2}{*}{ Urticaea } & Parietaria judaica \\
\hline 28 & & Urtica dioica \\
\hline
\end{tabular}


Areas with limited nutrients are similar to natural rocky areas (Jim, 1998). Hence, the plants in the study area were classified as RS (Ruderal-Stress tolerators) according to the Grime's C-SR model (Figure 3).

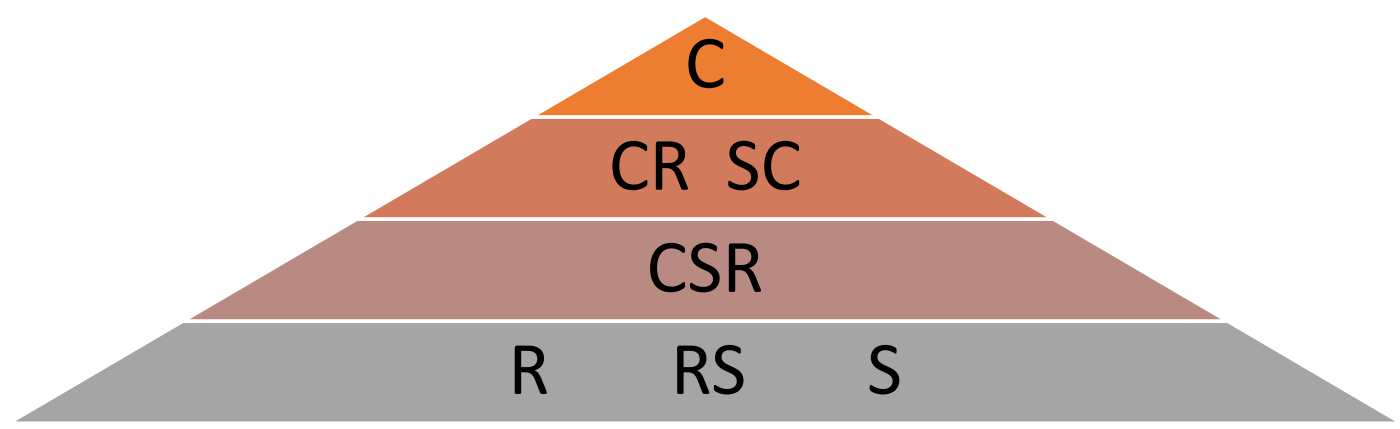

Figure 2. Grime's C-S-R triangle (C: Competitors, S: Stress-tolerators, R: Ruderal) [12]

$C$ : Abandoned, high-productivity areas, e.g. streamside

CR: Abandoned meadows

SC: High-productivity, disturbed areas, e.g. fertilized areas

CSR: Humid meadows

$\boldsymbol{R}$ : Abandoned, low-productivity meadows

$\boldsymbol{R S}$ : Disturbed, low-productivity areas, e.g. rocks

S: Disturbed fields

\section{Figure 3. Grime's C-S-R triangle (Şafak, 2015)}

The measurements in the study areas showed that the mean vegetation cover was $56.54 \%$ on the roofs, $29.37 \%$ on the walls in the sub-urban areas and $25.55 \%$ on the walls in the urban areas.

According to the One-Way ANOVA test performed for the study area with a confidence interval of $95 \%$, there were significant differences between the areas selected for the study (Table 2).

Table 2. One-Way ANOVA test for the cover density in study areas

\begin{tabular}{lccccc} 
ANOVA & \multicolumn{5}{l}{} \\
\hline Cover density & Sum of Squares & Df & Mean Square & F & Sig. \\
\hline Between Groups & 17543,558 & 2 & 8771,779 & 14,862 &, 000 \\
Within Groups & 54888,196 & 93 & 590,196 & & \\
Total & 72431,754 & 95 & & & \\
\hline
\end{tabular}

The Duncan test performed after the one-way ANOVA test revealed that although there were no significant differences between the walls in the urban and sub-urban areas in terms of vegetation density, the vegetation density of the walls and roofs was significantly different (Table 3). This is attributable to the easier retention of nutrient medium and water in roofs due to the horizontal elongation of the walls and their more favorable conditions for seed germination. 
Table 3. Duncan test for the cover density in study areas

Duncan $^{\mathrm{a}, \mathrm{b}}$

\begin{tabular}{|c|c|c|c|c|}
\hline \multirow{2}{*}{$\begin{array}{l}\text { Urban } \\
\text { Rural } \\
\text { Roofs }\end{array}$} & \multirow{2}{*}{$\begin{array}{l}\text { Walls- } \\
\text { Walls- }\end{array}$} & \multicolumn{3}{|c|}{ Subset for alpha $=0.05$} \\
\hline & & $\mathrm{N}$ & 1 & 2 \\
\hline 2 & & 30 & 28,03 & \\
\hline 1 & & 30 & 29,87 & \\
\hline 3 & & 36 & & 56,83 \\
\hline Sig. & & & ,764 & 1,000 \\
\hline
\end{tabular}

Means for groups in homogeneous subsets are displayed.

a. Uses Harmonic Mean Sample Size $=31,765$.

b. The group sizes are unequal. The harmonic mean of the group sizes is used. Type I error levels are not guaranteed.

The one-way ANOVA test performed for the study area with a confidence interval of $95 \%$ showed that there were no significant differences between the number of species in the areas selected for the study (Table 4).

Table 4. One-Way ANOVA test for the number of ruderal plant species in the study areas

ANOVA

\begin{tabular}{lccccc}
\hline Number of Species & & & & & \\
& Sum of Squares & df & Mean Square & F & Sig. \\
\hline Between Groups & 1,412 & 2 &, 706 & 1,093 &, 340 \\
Within Groups & 60,078 & 93 &, 646 & & \\
Total & 61,490 & 95 & & & \\
\hline
\end{tabular}

Despite the significant differences between the vegetation density on walls and roofs, the Duncan test showed that there were no significant differences between the number of species in different sample areas. Thus, it can be argued that the cover density in the study areas did not differ depending on the number of species.

The one-way ANOVA test performed for the study area with a confidence interval of $95 \%$ revealed that there were significant differences in anthropogenic effects in the areas selected for the study (Table 5).

Table 5. One-Way ANOVA test for the anthropogenic effects in study areas ANOVA

\begin{tabular}{lccccc}
\hline Anthropogenic effects & & & & & \\
& Sum of Squares & df & Mean Square & F & Sig. \\
\hline Between Groups & 95,855 & 2 & 47,928 & 37,727 &, 000 \\
Within Groups & 118,145 & 93 & 1,270 & & \\
Total & 214,000 & 95 & & & \\
\hline
\end{tabular}


The Duncan test performed for the anthropogenic effects showed that there were significant differences between the three sample areas in terms of anthropogenic effects. Thus, it can be argued that anthropogenic effects were an important factor in the differences between the vegetation density of the sample areas (Table 6).

Table 6. Duncan test for the anthropogenic effects in study areas

\begin{tabular}{lcccc}
\multicolumn{5}{l}{ Duncan ${ }^{\mathrm{a}, \mathrm{b}}$} \\
$\begin{array}{l}\text { Urban } \\
\text { Rural }\end{array}$ & $\begin{array}{c}\text { Walls- } \\
\text { Walls- }\end{array}$ & \multicolumn{5}{l}{} \\
Roofs & $\mathrm{N}$ & Subset for alpha $=0.05$ & 3 \\
\hline 3 & 37 & 1 & 2 & \\
2 & 29 & & & \\
1 & 30 & & 1,86 & 2,63 \\
Sig. & & 1,000 & 1,000 & 1,000 \\
\hline
\end{tabular}

Means for groups in homogeneous subsets are displayed.

a. Uses Harmonic Mean Sample Size = 31,631.

b. The group sizes are unequal. The harmonic mean of the group sizes is used. Type I error levels are not guaranteed.

According to the one-way ANOVA test performed for the study area with a confidence interval of $95 \%$, although there were no significant differences between the sunshine duration of the urban walls and roofs in the areas selected for the study, there were differences between urban walls and other two sample areas (Table 7).

Table 7. One-Way ANOVA test for the sunshine durations in study areas

ANOVA

\begin{tabular}{lccccc}
\hline Sunshine durations & & & & & \\
& Sum of Squares & df & Mean Square & F & Sig. \\
\hline Between Groups & 21,584 & 2 & 10,792 & 9,709 &, 000 \\
Within Groups & 103,374 & 93 & 1,112 & & \\
Total & 124,958 & 95 & & & \\
\hline
\end{tabular}

The examination of sunshine durations revealed that while there were no significant differences between the walls and roofs selected from the urban locations, the wall selected from the suburban location received less sunlight than the two areas (Table 8). On-site observations revealed that because of the lower vegetation of tall trees in the urban areas than that in the sub-urban areas, sunlight was only blocked by a limited number of tall trees and buildings in the urban areas, whereas it was frequently blocked both by the tall trees and buildings in the sub-urban areas. 
Table 8. Duncan test for the sunshine durations in the study areas

Duncan $^{\mathrm{a}, \mathrm{b}}$

\begin{tabular}{lccc}
\hline $\begin{array}{l}\text { Urban } \\
\text { Rural } \\
\text { Roofs }\end{array}$ & $\begin{array}{c}\text { Walls- } \\
\text { Walls- }\end{array}$ & Subset for alpha $=0.05$ & \\
\hline 1 & $\mathrm{~N}$ & 1 & 2 \\
3 & 30 & 1,23 & 2,03 \\
2 & 37 & & 2,41 \\
Sig. & 29 & &, 148 \\
\hline
\end{tabular}

Means for groups in homogeneous subsets are displayed.

a. Uses Harmonic Mean Sample Size = 31,631.

b. The group sizes are unequal. The harmonic mean of the group sizes is used. Type I error levels are not guaranteed.

The one-way ANOVA test performed for the study area with a confidence interval of $95 \%$ showed that the depths of the nutrient media in the areas selected for the study were significantly different from each other (Table 9).

Table 9. One-Way ANOVA test for the nutrient medium depths in the study areas

\begin{tabular}{lccccc} 
ANOVA & \multicolumn{1}{l}{} & & & \\
\hline Nutrient medium depths & & & & & \\
& Sum of Squares & df & Mean Square & Sig. \\
\hline Between Groups & 33,368 & 2 & 16,684 & 36,973 &, 000 \\
Within Groups & 41,965 & 93 &, 451 & & \\
Total & 75,333 & 95 & & & \\
\hline
\end{tabular}

The Duncan test showed that there were significant differences in the medium depths of all three sample areas (Table 10).

Table 10. Duncan test for the nutrient medium depths in study areas

Duncan $^{\mathrm{a}, \mathrm{b}}$

$$
\text { Subset for alpha }=0.05
$$

\begin{tabular}{lllll} 
Kir-Kent-Çat & N & 1 & 2 & 3 \\
\hline 2 & 29 &, 69 & & \\
1 & 30 & & 1,07 & 2,05 \\
3 & 37 & & & 1,000 \\
Sig. & & 1,000 & 1,000 &
\end{tabular}

Means for groups in homogeneous subsets are displayed.

a. Uses Harmonic Mean Sample Size = 31,631.

b. The group sizes are unequal. The harmonic mean of the group sizes is used. Type I error levels are not guaranteed.

\section{DISCUSSION and CONCLUSION}

Ecological studies about cities already fall short of understanding cities both quantitively and qualitatively, which is worsened by the ever-changing structure of the concept of city. This 
renders studies about cities even more important. Ruderal plants are among the most important subjects that require further research both to better understand cities and attach more significance to the concept of sustainability.

In times of constant information flow about the urban areas' gradual departure from habitability, more and more importance is attached to the sustainability concept. Sustainability in cities is an exhaustive term that involves tens of different components such as rainwater management, heat island effect, cycles of various materials such as carbon and nitrogen and pollination and plants have important roles in all of these components. Although this is not a major problem in sub-urban areas, urban areas indicate habitats that are hard to adapt to for many plant species. In addition, the green areas in sub-urban areas are frequently replaced by floor coverings and roofing in urban areas, which turn urban areas into problem areas in terms of various ecological parameters. Hence, as species with high adaptability to the conditions of urban areas where maintenance costs are becoming more important and living conditions are getting worse, a further insight into ruderal plants, revealing their characteristics and using them as the support material for the plant materials used in cities to, if possible, minimize the need for maintenance will be among the most important steps taken for modern cities. A noteworthy portion of the common species that were identified in the study area can also be utilized as landscaping plants and thus, creating a preference for their use in urban landscaping will prove fruitful. The use of expensive and non-sustainable methods to sustain the plant materials used on almost all humanmade green walls instead of Parietaria Judaica, which is a taxon referred to as "pellitory of the wall" in the scientific literature and thrives on walls in many regions of the world despite the far from ideal conditions of walls in terms of water and nutrient supply, is quite ironic. Rather than using non-sustainable and expensive methods to facilitate the conditions for the exotic species used on green walls and green roofs use of which emerged in response to sustainability and global climate change channeling the ruderal plant resources, which are already available in urban areas and have the capacity to compete, to these areas is a more ecofriendly approach. As a dynamic group characterized by their resistance to ever-changing conditions, ruderal plants can be regarded as a part of the urban areas' richness in biodiversity. Although degraded areas are the reason of their existence, considering the dynamics of cities, other plants are unlikely to exist in areas where ruderal plants are not already present and therefore, the presence of ruderal plants in areas where maintenance is not necessary or expensive implies an automatic increase in biodiversity. An uninhabitable living area even for ruderal plants means that area is exhausted to its limits and thus, ruderal plants can also be viewed as an indicator of the not yet diminished potential of urban ecosystems to support organic life. 
The differences and similarities between the ruderal plants in sub-urban areas and urban areas also have an important potential to shape the future of cities. Especially the sub-urban areas in developing countries are candidate urban areas and therefore, the examination and prospective interpretation of the dynamics in these areas will greatly contribute to our understanding of urban ecosystems. These areas harbor urban dynamics in a lesser degree and determining where the ecological differences-induced similarities and differences between the ruderal vegetations in the two areas start and end will enable the suburbanization of the urban areas through the use of ruderal plants and thus, result in the start of a comeback for urban areas.

Although the one-way ANOVA and Duncan tests with a confidence interval of $95 \%$ indicated that there were no significant relationships between the number of species and medium depths in the sample areas, significant relationships were found between anthropogenic effects and nutrient medium depths. The regression analysis performed after these tests showed that anthropogenic effect and nutrient medium depth were the most effective parameters on cover density (Table 11).

Table 11. Regression analysis for the study areas

Coefficients $^{\mathbf{a}}$

\begin{tabular}{|c|c|c|c|c|c|c|}
\hline & & \multicolumn{2}{|c|}{$\begin{array}{l}\text { Unstandardized } \\
\text { Coefficients }\end{array}$} & \multicolumn{3}{|c|}{$\begin{array}{l}\text { Standardized } \\
\text { Coefficients }\end{array}$} \\
\hline \multicolumn{2}{|c|}{ Model } & $\mathrm{B}$ & Std. Error & Beta & $\mathrm{t}$ & Sig. \\
\hline \multirow[t]{5}{*}{1} & (Constant) & 3,001 & ,344 & & 8,724 &, 000 \\
\hline & Number of species &,- 159 &, 142 &,- 092 & $-1,125$ & ,264 \\
\hline & Anthropognic effects &,- 427 &, 078 &,- 461 & $-5,475$ &, 000 \\
\hline & Nutrient medium depths &, 569 & ,137 & ,369 & 4,164 &, 000 \\
\hline & Sunshine durations &,- 218 &, 095 &,- 181 & $-2,295$ & ,024 \\
\hline
\end{tabular}

a. Dependent Variable: Cover density

Therefore, it can be concluded that medium depth is the most important parameter to be supplied to improve the ecological parameters in urban areas through the use of ruderal plants. Nutrient medium depth was revealed to be the most important parameter, since the plants tolerated and adapted to other conditions. From this point of view, creating small niches to allow the adherence of nutrient media in the hard surfaces used in the landscape design while also taking the physical integrity of the construction and visual quality into account can greatly contribute to the relief of the cities of the green infrastructure load. Using roof tiles that contain small pockets as roof covering, preferring pocket-containing materials as wallcovering, using rocks with large pores and constructing wide cracks for drainage are exemplary ways to create niches for this purpose. 


\section{REFERENCES}

Anonymous 2018a. https://en.wikipedia.org/wiki/Ruderal_species (Access on: 27.09.2018)

Anonymous 2018b. https://www.diyadinnet.com/YararliBilgiler-746\&Bilgi=trabzonun-co\%C4\%9 Frafyas\% C4\% B1-ve-co\%C4\%9Frafi-konumu-yap\%C4\%B1s\%C4\%B1 (Access on: 27.09.2018)

Altay, V., Karahan, F., 2017. Ruderal Vejetasyon Üzerine Bir Ön Çalışma: Antakya (Hatay) Örneği, Kilis 7 Araslık Üniversitesi Fen ve Mühendislik Dergisi, 1(2) : 68-77.

Altay, V., 2009. İstanbul'un Anadolu Yakası'nın Kentsel Vejetasyonu. Marmara Üniversitesi, Fen Bilimleri Enstitüsü Biyoloji Anabilim Dalı, Doktora tezi, 436 p.

Coşkunçelebi, K., Terzioğlu, S., Vladimirov, V., 2007. A New Alien Species For the Flora of Turkey: Bidens frondosa L. (Asteraceae), Turkish Journal of Botany, 31 : 477-479.

Çelik, A., Şeşen, B., Aksoy, A., Öztürk, M. 1998. Priene (Söke-Aydın) kentinde fitoekolojik gözlemler. Büyük Menderes Havzası 3. Tarım ve Çevre Sempozyumu, 2-4 Eylül 1998, Söke-Aydın.

Çetin, N., Mansuroğlu, S., 2018. Akdeniz Koşullarında Kurakçıl Peyzaj Düzenlemelerinde Kullanılabilecek Bitki Türlerinin Belirlenmesi, Ege Üniversitesi Ziraat Fakültesi Dergisi, 55(1) : 11-18.

Davis, P.H., Mill, R.R., Tan, K., 1988. Flora of Turkey and the East Aegean Islands, Edinburgh University Press, Edinburgh, V: 10.

Davis, P., H., 1965-1985. Flora of Turkey and the East Aegean Islands, Edinburgh University Press, Edinburgh, V: 1-9.

Dogan, Y., Baslar, S., Celik, A., Mert, H. H., Ozturk, M., 2004. A study of the roadside plants of West Anatolia, Turkey. Natur. Croatia, 13(1): 63-80.

Eminağaoğlu, Ö., Özcan, M., Kültür, Ş., 2012. Contributions to the leaf and stem anatomy of Tradescantia fluminensis: an alien species new to the flora of Turkey. Artvin Çoruh Üniversitesi Orman Fakültesi Dergisi, 13(2) : 270.

Erik, S., 2012. Çok Yönlü Bir Ruderal Tür: Diplotaxis tenvifolia (L), Ankara Üniversitesi Çevrebilimleri Dergisi, 4(1) : 27-35.

Frenkel, R., E., 1977. Ruderal Vegetation along Some California Roadsides. University of California Press, Berkeley-Los Angeles. 173 p.

Güner, A., Aslan, S., Ekim, T., Vural, M., Babaç, M., T., 2012. Türkiye Bitkileri Listesi (Damarlı Bitkiler). Nezahat Gökyiğit Botanik Bahçesi ve Flora Araştırmaları Derneği Yayını, İstanbul, 1290p. 
Güner, A., Özhatay, N., Ekim, T., Başer, K.H.C., 2000. Flora of Turkey and the East Aegean Islands, Suppl. 2. Edinburgh University Press, Edinburgh, 11: 680p.

Güney, K., Geven, F., Bingöl, M., Ü., 2006. Kastamonu ili ruderal vejetasyonunun sintaksonomik analizi. TÜBİTAK Tarım, Ormancılık ve Veterinerlik Araştırma Grubu Proje No: TOVAG-1050022.

Hadac, E., 1978. Folia Geobotanica et Phytotaxonomica. 13 : 129-163.

Hamel, A., Dansereau, P., 1949. L'aspect écologiqu du probleme des mauvaises herbes. University of Montreal, Canada. 45 p.

Heindl, B., Ulmann, I., 1991. Road Vegetation in Mediterranean France, Phytocoenologia, 20(1) : 111-141.

Jim, C., Y., 1998. Old Stone Walls as an Ecological Habitat for Urban Trees in Hong Kong, Landscape and Urban Planning, 42(1) : 29-43.

Karahan, F., Çelik, O., Kayikçi, S., Altay, V., 2012. Antakya (Hatay)'nın ayakaltı bitkileri. Biyoloji Bilimleri Araştırma Dergisi, 5(2), P: 135-137.

Karaköse, M., Akbulut, S., Bayramoğlu, M., 2018. Espiye (Giresun) Orman Planlama Birimi’nin İstilacı Yabancı Türleri, Türkiye Ormancılık Dergisi, 19(2), P: 120-129.

Ketenoğlu, O., Vural, M., Kurt, L., Körüklü, T., 2014. Vejetasyon, Resimli Türkiye Floras1, Ali Nihat Gökyiğit Vakfı, Flora Araştırmaları Derneği ve Türkiye İş Bankası Kültür Yayınları yayını, İstanbul, $1: 163-224$,

Kılınç, M., Kutbay, H., G., 2008. Grime'in Bitki Stratejileri, Bitki Ekolojisi, Ankara Palme Yayıncılık, S: 356-359.

Önen, H., 2015. Türkiye İstilâcı Bitkiler Kataloğu. Ezgi Ofset Matbaacılık, Ankara 193p.

Pianka, E.R., 1970. On r- and k-selection. The American Naturalist, 104 : 592-597.

Raunkiaer, C., 1937. The life forms of plants and statictical plant geography, Clarendon Press, Oxford, 147p.

Rentch, J., S., Fortney, R., H., Stephenson, S., L., Adams, H., S., Grafton, W., N., Anderson, J., T., 2005. Vegetation-Site Relationships of Roadside Plant Communities in West Virginia, USA, Journal of Applied Ecology, 42 : 129-138.

Sakai, A.K., Allendorf, F.W., Holt, J.S., Lodge, D.M., Molofsky, J., With, K.A., Baughman, S., Cabin, R.J., Cohen, J.E., Ellstrand, N.C., McCauley, D.E., O’Neil, P., Parker, I.M., Thompson, J.N., Weller, S.G., 2001. The population biology of invasive species. Annual Review of Ecology, Evolution, and Systematics, 32 : 305-332.

Sukopp, H., Wittig, R., 1998. Stadtökologie. Ein Fachbuch für Studium und Praxis. Fischer Verlag, Stuttgart. 402 p. 
Şafak, S., A., 2015. Ruderal Vejetasyon, Ordu Üniversitesi Bilim ve Teknoloji Dergisi, 5(2) : 74-82.

Terzioğlu, S., Anşin, R., Kanoğlu, E., 2003. A new record for Turkey: Solidago canadensis L. Turkish Journal of Botany, 27 : 155-157.

Terzioğlu, S., Anşin, R., 1999. A contribution to exotic plants of Turkey: Sicyos angulatus L. Turkish Journal of Agriculture and Forestry, 23(3) : 359-362.

Yarcı, C., Altay, V., 2016. Kocaeli ve çevresindeki tarım alanlarının yabani ot florası. Erzincan Fen Bilimleri Enstitüsü Dergisi, 9(2) : 148-171.

Yalçınalp, E., Meral, A., 2017. Wall Vegetation Characteristics of Urban and Sub-Urban Areas, Sustainability, $9: 1691-1706$.

Yüzbaşığlu, İ., S., 2014. Oenothera parodiana (Onagraceae): a new alien species record for the flora of Turkey. Biological Diversity and Conservation, 7(2) : 122-126. 